\title{
Factors associated with exclusive breastfeeding in the Legal Amazon and Northeast regions, Brazil, 2010
}

\section{Fatores associados ao Aleitamento Materno}

Exclusivo na Amazônia Legal e no

Nordeste, Brasil, 2010

Alice Cristina Medeiros das NEVES

Erly Catarina MOURA²

Wallace SANTOS 3

Kênia Mara Baiocchi de CARVALHO'

\section{A B S T R A C T}

\section{Objective}

The objective of this study was to identify the factors associated with exclusive breastfeeding in children aged less than six months from the Brazilian Legal Amazon and Northeast regions.

\section{Methods}

The study used data from a survey that assessed prenatal and infant ( $<1$ year) care in 2010. Sociodemographic, prenatal, delivery, and puerperium care factors with $p<0.05$ in multivariate analysis were associated with exclusive breastfeeding.

\section{Results}

For both regions, the prevalence of exclusive breastfeeding decreased with age, which was the main variable associated with early weaning. In the Legal Amazon, exclusive breastfeeding prevailed among: mothers aged 35 years or more; mothers living in state capitals; and mothers who breastfed on the first hour of life. In the Northeast, the probability of exclusive breastfeeding was greater for mothers aged 35 years or more.

\footnotetext{
1 Universidade de Brasília, Faculdade de Ciências da Saúde, Programa de Pós-Graduação em Nutrição Humana. Campus Universitário Darcy Ribeiro, Asa Norte, 70910-900, Brasília, DF, Brasil. Correspondência para/Correspondence to: ACM NEVES. E-mail: <lica_medeiros@hotmail.com>.

2 Ministério da Saúde, Secretaria de Vigilância em Saúde. Brasília, DF, Brasil.

${ }^{3}$ Universidade de Brasília, Faculdade de Ciências da Saúde, Programa de Pós-Graduação em Ciências da Saúde. Brasília, DF, Brasil.

Support: Ministério da Saúde, Departamento de Ciências e Tecnologia.
} 


\section{Conclusion}

The factors associated with exclusive breastfeeding were child's and mother's age in both regions; and residence location and breastfeeding in the first hour of life in the Legal Amazon, suggesting the need of differentiated strategies for the promotion of exclusive breastfeeding.

Indexing terms: Breast feeding. Epidemiologic factors. Epidemiology. Infant.

\section{R E S U M O}

\section{Objetivo}

O objetivo foi identificar fatores associados ao aleitamento materno exclusivo em crianças menores de seis meses de idade, residentes na Amazônia Legal e no Nordeste do Brasil, com base nos dados da pesquisa de avaliação da atenção ao pré-natal e aos menores de um ano de idade em 2010.

\section{Métodos}

Consideraram-se fatores associadas ao aleitamento exclusivo as variáveis sociodemográficos e de assistência ao pré-natal, parto e puerpério que mantiveram p<0,05 em análise multivariada.

\section{Resultados}

Em ambas as regiões, a prevalência de aleitamento materno exclusivo apresentou declínio com aumento da idade da criança, que se configurou na principal variável associada ao desmame precoce. Na Amazônia Legal, a probabilidade de aleitamento materno exclusivo foi maior para: mães com 35 ou mais anos de idade, mães que residiam nas capitais dos estados e mães que amamentaram na primeira hora de vida da criança. No Nordeste, a probabilidade de aleitamento materno exclusivo também foi maior para mães com 35 ou mais anos de idade.

\section{Conclusão}

Os fatores associados ao aleitamento materno exclusivo foram idade da criança e idade da mãe nas duas regiões, localização de moradia e mamada na primeira hora na Amazônia Legal, o que sugere a necessidade de estratégias diferenciadas para a promoção do aleitamento materno.

Termos de indexação: Aleitamento materno. Fatores epidemiológicos. Epidemiologia. Lactente.

\section{INTRODUCTION}

Exclusive breastfeeding is understood as feeding an infant breast milk only, either directly from a breast or extracted from the mother or a donor, and no other fluid or solid, except for vitamin, mineral, or medical drops or syrups ${ }^{1}$. The actions for promoting, protecting, and supporting breastfeeding are effective and inexpensive strategies against childhood morbidity and mortality ${ }^{2}$. The World Health Organization $(\mathrm{WHO})^{3}$ recommends exclusive breastfeeding for six months and non-exclusive breastfeeding for at least two years, and the Brazilian Ministry of Health $(\mathrm{MH})^{4}$ has supported the recommendation since 2001. Breastfeeding is closely related to the child's good nutritional and health statuses, and to greater resistance against infectious diseases, especially gastrointestinal infections.
Breastfeeding may reduce the preventable death rates of children less than five years of age by as much as $13 \%$ worldwide ${ }^{5}$. Although childhood mortality is decreasing in Brazil6, reducing preventable deaths is a permanent challenge, and the rates represent a public health problem that affects Brazilian regions differently?. In the North and Northeast regions, these rates are still high, so in 2009 the Pact for Reducing Childhood Mortality was signed in the Northeast and Legal Amazon to reduce these regional inequalities. The pact has six cores, one of them being prenatal, delivery, and newborn care qualification ${ }^{8}$.

Some Brazilian studies conducted at the end of the $20^{\text {th }}$ century covering a period of 25 years already detected a gradual improvement in the breastfeeding practices of the children less 
than one year of age, but the breastfeeding indicators varied significantly throughout the different geographic regions of the country9,10. Brazil has a high percentage of mothers who start breastfeeding their children (95.0\%), but exclusive breastfeeding does not reach the ideal duration, being much smaller than the recommended six months. The 2006 Pesquisa Nacional de Demografia e Saúde da Criança e da Mulher (PNDS, National Child's and Mother's Demographic and Health Survey) ${ }^{11}$ found an exclusive breastfeeding rate of $38.6 \%$ in children less than six months of age, with the Northeast region having the lowest median: 1.1 months. The II Breastfeeding Prevalence Survey ${ }^{12}$ conducted in 2008 in Brazilian capitals and Distrito Federal found an exclusive breastfeeding rate of $41.0 \%$ in children aged less than six months, with the highest and lowest prevalences occurring in the North $(45.9 \%)$ and Northeast (37.0\%) regions, respectively.

Given this landscape, investigation of the possible factors associated with exclusive breastfeeding in children aged less than six months is one of the requirements for promoting exclusive breastfeeding policies and programs, and identifying the occasions that most contribute to early weaning. The present study assesses this aspect in municipalities of the Legal Amazon and Northeast regions in 2010 using data from the survey "Neonatal Call: assessment of prenatal care and care of infants aged less than one year in the North and Northeast regions".

\section{METHODS}

This study is based on secondary data from the "Neonatal Call: assessment of prenatal care and care of infants aged less than one year in the North and Northeast regions" conducted in 2010 and approved by the Research Ethics Committee of Escola Nacional de Saúde Pública Sérgio Arouca/Fundação Oswaldo Cruz (Ensp/Fio Cruz). The cross-sectional study included mothers of children aged less than one year who received the multiple vaccines in 252 of the 256 primary municipalities of the Pact for Reducing Childhood Mortality ${ }^{8}$. The municipalities are located in nine states of the Legal Amazon (Acre, Amapá, Amazonas, Maranhão, Mato Grosso, Pará, Roraima, Rondônia, and Tocantins) and in eight states of the Northeast region (Alagoas, Bahia, Ceará, Paraíba, Pernambuco, Piauí, Rio Grande do Norte, and Sergipe).

The Neonatal Call used probabilistic sampling to select the children vaccinated in each planned domain: the capital of each state and all other municipalities of the state. The minimum sample size of each domain, 750 mother/child dyads, was estimated considering a delivery complication of $22.0 \%{ }^{13}$, an error $\leq 3.5 \%$, a confidence coefficient $\geq 95.0 \%$, and a design correlation factor (deff) $\leq 1.5$, totaling 23,399 interviews. The mother/child dyads were selected by two-stage cluster sampling ${ }^{14}$ and probability proportional to cluster size. The first stage randomly selected the main vaccination stands in each municipality; the second stage consisted of a systematic selection of mother/child dyads at each vaccination stand, according to the study inclusion criteria. Mothers of children aged more than one year, living in other municipalities, and whose children were twins and/or adopted were excluded. A total of 16,863 mothers of children aged less than one year were interviewed, corresponding to a $3.5 \%$ to $4.4 \%$ increase in the sampling error while maintaining all other samplesize calculation criteria fixed.

A pretested form with closed questions on demographic and socioeconomic characteristics was used for collecting the following data; prenatal, delivery, and puerperium care; and child's growth and feeding; among others.

The present study included only the mothers of children aged less than six months $(n=9,090) ; 30$ were excluded because of missing data about the child's diet so only 9,060 forms were valid. The study sample size conforms to the sampling error criteria of 2.2, confidence coefficient of $95.0 \%$, deff $=2.0$, considering the real prevalence of the study outcome (exclusive 
breastfeeding prevalence of 39.9\%), allowing stratification by region.

The study dependent variable was exclusive breastfeeding, classified as yes or no. The child was considered to be exclusively breastfed when the child was fed only breast milk and no other fluid or solid, as recommended by the $\mathrm{WHO}^{1}$. The 24-hour dietary recall was used to identify the breastfeeding and/or feeding practices. The questionnaire included questions about the intake of breast milk, other types of milk, and other foods, including water, tea, and other fluids in the previous 24 hours. Thus, the instrument indicates whether the child was exclusively breastfed in the 24 hours before the interview ${ }^{15,16}$.

The independent variables were child's characteristics (age, gender, and birth weight); mother's sociodemographic characteristics (age, education level, skin color, and location of residence); prenatal care characteristics (attending prenatal care, prenatal care location, and advice on breastfeeding during prenatal care); delivery (type of delivery and delivery location); puerperium care (breastfeeding in the first hour of life, rooming-in, and recent visit from a health agent or Family Health Strategy agent).

The study sample distribution was assessed according to sociodemographic, and prenatal, delivery, and puerperium care variables (total and by region) with a Confidence Interval of $95 \%$ $(95 \% \mathrm{Cl})$. The exclusive breastfeeding prevalence was calculated for each month of the child's age with a 95\% Cl for all sociodemographic, prenatal, delivery, and puerperium variables, separately and by region, according to the Chi-square test $\left(\chi^{2}\right)$. The exclusive breastfeeding Prevalence Ratio (PR) and respective $95 \% \mathrm{Cl}$ were calculated and stratified by region (Legal Amazon and Northeast region) by Poisson Regression adjusted for all variables. The significance level was set at $5 \%$ $(p<0.05)$.

All estimates take into consideration the study design, correcting for the clustering effect and giving individual weights proportional to sampling probability. The weighting factor according to the number of children aged less than one year of each municipality, according to the 2010 Census, was also considered (http:// www.ibge.gov.br). The data were treated by the software Stata version 11.0, using the svy command, with a significance level of $5 \%$ $(p<0.05)$ and $95 \% \mathrm{Cl}$.

\section{RE S U L T S}

Of the 9,060 study children, 4,116 were from the Legal Amazon and 4,944 were from the Northeast regions; both groups had similar ages and gender distribution. Roughly $94 \%$ of the children in both regions had normal birth weight.

Most mothers from both regions were 20 to 34 years old, finished high school, were Black, lived in urban areas other than the capital, attended prenatal care at a public service, received breastfeeding advice during prenatal care, delivered at a public service, breastfed in the first hour of life, and were roomed-in with their child. In the Legal Amazon, most of the study mothers had not been visited by the health agent or Family Health Strategy agent, unlike the Northeast mothers who had (Attached 1).

The prevalence of exclusive breastfeeding on the first month of life was $72.0 \%$, decreasing to $57.5 \%, 49.9 \%, 39.5 \%, 24.4 \%$, and $11.6 \%$ from the second to the sixth months in the study Legal Amazon municipalities. In the Northeast region, exclusive breastfeeding also decreased, reaching $13.3 \%$ at six months of age but starting at $66.3 \%$. The prevalence of exclusive breastfeeding in the Northeast sample was statistically lower than that in the Legal Amazon sample, but equal when compared on a monthly basis (Figure 1).

In the Legal Amazon municipalities, the prevalence of exclusive breastfeeding was greater among older women, reaching $48.1 \%$ in mothers aged more than 35 years; in those who breastfed the child in the first hour of life; and in those who had not been visited recently by a health agent or Family Health Strategy agent $(p<0.05)$. 


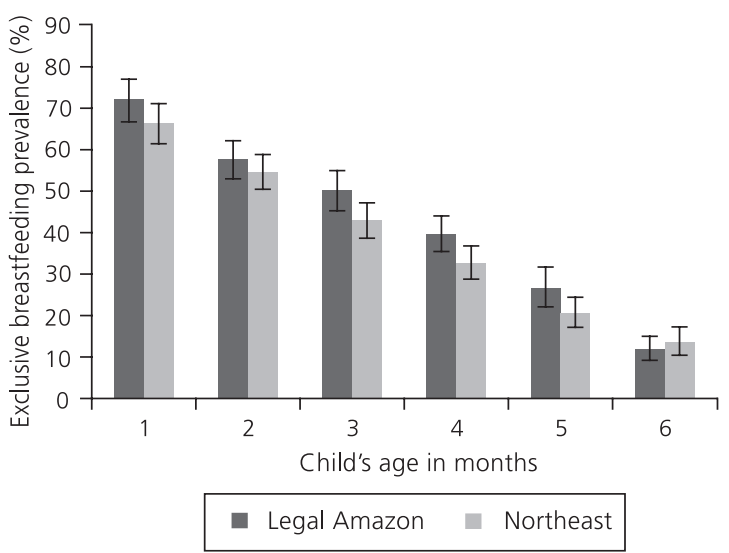

Figure 1. Distribution of the prevalence of exclusive breastfeeding and confidence interval of $95 \%$ according to the child's age in months. Children younger than six months of age living in the study municipalities of the Legal Amazon and Northeast regions. Brazil, 2010.

In the Northeast municipalities, the prevalence of exclusive breastfeeding increased with mother's age, reaching $45.6 \%$ in the mothers aged $\geq 35$ years; in those who attended prenatal care; and in those who had been visited recently by a health agent or Family Health Strategy agent $(p<0.05)$ (Attached 2).

Multivariate analysis identified the child's age as the main variable associated with early weaning in both regions (Attached 3). The mother's age comes next: children whose mothers are older than 34 years are $28 \%$ and $42 \%$ more likely to be exclusively breastfed in the Legal Amazon and Northeast regions, respectively, than those of mothers aged less than 20 years. Living in the State Capital (17\%) and breastfeeding in the first hour of life (16\%) were protective factors only in the Legal Amazon.

\section{I S C U S S I O N}

The objective of this study was to investigate the factors associated with exclusive breastfeeding in children aged less than six months from primary municipalities in the Legal Amazon and Northeast regions of Brazil, since the literature has indicated that early weaning is strongly influenced by geographic region ${ }^{17}$. This situation was confirmed by the present study: exclusive breastfeeding was associated with different factors in the two study regions. The variables associated with exclusive breastfeeding were: child's age, mother's age, location of residence, and breastfeeding in the first hour of life, but the associations varied by region.

The prevalence of exclusive breastfeeding in children aged less than six months found by the present study (39.9\%) was similar to that found by the II Breastfeeding Prevalence Survey $(41.0 \%)$, including variation by region ${ }^{16}$. In the present study, the prevalence of exclusive breastfeeding in the selected Northeast municipalities was lower in children aged less than six months, but equal to that of the Legal Amazon when compared by month, declining sharply with the child's age. The decreasing prevalence of exclusive breastfeeding with child's age was also observed by Pereira et al. ${ }^{18}$ in a study of 1,029 mothers of children aged less than six months frequenting primary health care units in the city of Rio de Janeiro: the prevalence of breastfeeding decreased by $17.0 \%$ per month of the child's life.

One can see that, in Latin American countries, exclusive breastfeeding duration varies greatly. Data from demographic and health surveys show that the median breastfeeding duration of four months in Bolivia was much greater than the medians in Brazil (1.4 months), El Salvador (1.4 months), Dominican Republic (0.5 months), and Haiti (0.4 months), countries with the lowest medians ${ }^{11,19}$.

The mother's age was strongly associated with exclusive breastfeeding in both regions. The prevalence of exclusive breastfeeding was greater among older mothers even after adjustment: higher mother's age was a protective factor for exclusive breastfeeding. These results are similar to those found by Venâncio \& Monteiro ${ }^{20}$ in a study of 34,435 children younger than six months of age from 111 municipalities in the state of São Paulo, which found that the duration of exclusive breastfeeding increased with mother's age until the age group of 25 to 29 years. Saldiva et al. ${ }^{17}$ 
studied 18,929 children aged less than six months from the II National Breastfeeding Prevalence Survey and found that adolescent mothers (<age 20 years) were more likely to introduce porridge early.

Breastfeeding within the first hours after birth is important for breastfeeding maintenance, and is a recommendation of the Pan-American Health Organization ${ }^{21}$. After adjustment for all variables included in multiple analysis, the variable breastfed within the first hour after birth' remained in the model as a protective factor for children aged less than six months from the Legal Amazon region and the study state capitals.

Santos et al. ${ }^{22}$ studied the factors associated with preventable deaths in children aged less than four years in a cohort born in Rio Grande do Sul and found that not being breastfed within the first 24 hours of life was associated with a higher risk of dying from preventable causes, even after adjustment for confounders. Not being breastfed in the first 24 hours of life reduces the prevalence of breastfeeding 23,24 . Although marginally, breastfeeding within the first hour of life is conceptually important and according to many studies, promotes breastfeeding. Therefore, promoting breastfeeding in the first 24 hours after delivery it is an essential prenatal care activity.

In adjusted data from household surveys on mother mother/child nutrition in the State of Pernambuco, Carminha et al. ${ }^{25}$ found that living in the Metropolitan Region of Recife promoted exclusive breastfeeding. Living in the state capital strongly indicates access to health services and strategies that promote and encourage breastfeeding. On the other hand, Ramos et al. ${ }^{23}$ and Demétrio et al. ${ }^{26}$ pointed out that living in an urban area hinders breastfeeding.

Integrated actions covering prenatal care, delivery care, and post-delivery support work together to improve the quality of care provided to women who breastfeed ${ }^{27}$.

Demétrio et al. ${ }^{26}$ in a cohort from municipalities in the Recôncavo Region of Bahia,
(BA) found that the median duration of exclusive breastfeeding is proportionally smaller in women who do not attend prenatal care. During prenatal care health professionals have a positive influence on breastfeeding duration, both as breastfeeding educators and promoters. In this study, the Northeast region presented the highest prevalence of exclusive breastfeeding among mothers who attended prenatal care. However, after adjustment for the confounders, this association lost significance.

According to the $\mathrm{WHO}$, health agents increase exclusive breastfeeding duration more effectively than any other professional ${ }^{28}$. However, the present study found that exclusive breastfeeding prevalence was higher in both regions among mothers who had not been recently visited by Family Health Strategy professionals. After adjustment in multiple analysis, this factor was not associated with breastfeeding prevalence. Studies that assessed Family Health Strategy teams' knowledge about breastfeeding found that although the professionals were well informed about the advantages of breastfeeding, few knew how to manage breastfeeding appropriately in the clinical setting ${ }^{29-31}$. Hence, one has to assess the efficacy of these actions, since so far they have not been enough to promote exclusive breastfeeding in the two study regions.

The main variable associated with exclusive breastfeeding was child's age: in the second month, there was a $20 \%$ risk of introducing other foods; in the sixth month, the risk increased to $80 \%$. Considering that the country has been advancing breastfeeding since 1981 with different breastfeeding-promoting actions, the data shown herein are concerning despite the increase in exclusive breastfeeding duration from 23.4 days to 54.1 days between 1999 and $2008^{16}$. The Neonatal Call ${ }^{32}$ identified a median exclusive breastfeeding duration of 64 days (76 in the Legal Amazon and 58 in the Northeast) in children aged less than six months, confirming the exclusive breastfeeding prevalence curves shown in Attached 1. 
However, this type of study is not enough to identify the causes of introducing foods early. The question is: why do mothers introduce foods early? Is it a cultural and/or social issue or is it encouraged by health professionals and/or services? Many variables associated with early weaning are cited in the literature and should be assessed by other types of studies, such as: lack of information about the importance of breastfeeding, overestimating the benefits of weaning foods, maternal work, cultural habits, and social representations, among others.

The main limitations of this study are: its cross-sectional nature does not allow differentiating between cause and effect; and the fact that data collection used a method subject to memory bias, despite its recognized advantages (the WHO warns that the 24 hours can overestimate the proportion of exclusively breastfed children since some children are given other fluids occasionally) ${ }^{15,33}$. The fact that the survey was conducted on the National Immunization Day (D-day) may also have been a limiting factor because it was not possible to survey a high percentage of the population on a single day: the vaccination period was extended, especially in hardly accessible regions, but this situation was somewhat remediated because surveys on vaccination day are still a widely used and recommended strategy in Brazil ${ }^{34}$.

Although the study findings may represent the children from the study municipalities and other similar children, the $2.2 \%$ sampling error and $95.0 \% \mathrm{Cl}$ does not allow extrapolation to all children in the Brazilian Legal Amazon and Northeast regions.

\section{CONCLUSION}

In a heterogeneous country like Brazil, one should expect different regional breastfeeding practices, and this study confirmed that the factors associated with exclusive breastfeeding are influenced by the geographic region of the country. The factors associated with exclusive breastfeeding in children aged less than six months were child's age, mother's age, residence location, and being breastfed in the first hour of life, but distinctively by region.

Higher child's age was a risk factor for non-exclusive breastfeeding in both regions. In the study Legal Amazon municipalities, the probability of exclusive breastfeeding was greater among mothers aged 35 years or more. A similar situation was observed in the Brazilian Northeast. Breastfeeding in the first hour after birth and living in the state capital promote exclusive breastfeeding only in the Legal Amazon region.

These findings may be useful for defining differentiated breastfeeding promotion strategies according to the most common characteristics of each region. Strategies that should be assessed for promoting exclusive breastfeeding are the prenatal, delivery, and puerperal care that aim to reduce the early feeding of fluids or foods to children aged less than six months and to improve the processes that change hospital routines in the main maternity hospitals of the Legal Amazon and Northeast regions. Moreover, health professionals need to be better qualified with respect to managing exclusive breastfeeding until age six months as recommended by the WHO and $\mathrm{MH}$, because of the strong reduction in the prevalence of exclusive breastfeeding.

\section{CONTRIBUTORS}

ACM NEVES helped to design the methods, tabulate the data, analyze the results, and write the manuscript. EC MOURA helped to design the methods, analyze the data, and review the manuscript. W SANTOS helped to tabulate the data and analyze the results. KMB CARVALHO helped to review the manuscript.

\section{REFERE NCES}

1. World Health Organization. Division of Child Health and Development. Indicators for assessing breastfeeding practices. Geneva: WHO; 1991.

2. World Health Organization. The optimal duration of exclusive breastfeeding: Report of an expert consultation. Geneva: WHO; 2001. 
3. World Health Organization. Infant and young child feeding: A tool for assessing national practices, policies and programs. Geneva: WHO; 2003.

4. Brasil. Ministério da Saúde. Secretaria de Políticas de Saúde. Guia alimentar para crianças menores de dois anos. Brasília: Ministério da Saúde; 2002.

5. Jones G, Steketee RW, Black RE, Bhutta ZA, Morris SS, Bellagio Child Survival Study Group. How many child deaths can we prevent this year? Lancet. 2003; 362(9377):65-71.

6. United Nations Children's Fund. Committing to child survival: A promise renewed. New York: Unicef; 2012.

7. Brasil. Ministério da Saúde. Secretaria de Atenção à Saúde. Manual dos comitês de mortalidade materna. $3^{a}$ ed. Brasília: Ministério da Saúde; 2007. Série A. Normas e Manuais Técnicos.

8. Brasil. Ministério da Saúde. Secretaria de Atenção à Saúde. Pacto pela redução da mortalidade infantil no Nordeste e Amazônia Legal: 2009-2010. Brasília: Ministério da Saúde; 2011.

9. Sena MCF, Silva EF, Pereira MG. Tendência do aleitamento materno no Brasil no último quarto do século XX. Rev Bras Epidemiol. 2007; 10(4):499-505.

10. Brasil. Ministério da Saúde. Secretaria de Atenção a Saúde. Pesquisa de prevalência do aleitamento materno em municípios brasileiros. Brasília: Ministério da Saúde; 2010.

11. Segall-Correa AM, Marín-León L, Panigassi G, Rea MF, Pérez-Escamilla R. Amamentação e alimentação infantil. In: Brasil. Ministério da Saúde. Secretaria de Ciência, Tecnologia e Insumos Estratégicos. Pesquisa nacional de demografia e saúde da criança e da mulher. Brasília: Ministério da Saúde; 2009.

12. Brasil. Ministério da Saúde. Secretaria de Atenção a Saúde. II Pesquisa de prevalência do aleitamento materno nas capitais e Distrito Federal. Brasília: Ministério da Saúde; 2009.

13. Brasil. Ministério da Saúde. Chamada Nutricional da Região Norte 2007. Resumo Executivo 2009. Brasília: Ministério da Saúde; 2009.

14. Silva NN. Amostragem probabilística: um curso introdutório. São Paulo: Edusp; 1998.

15. World Health Organization. Indicators for assessing infant and young child feeding practices: Conclusions of a consensus meeting held 6-8 November 2007 in Washington DC, USA. Washington (DC): WHO; 2008.

16. Venâncio SI, Escuder MML, Saldiva SRD, Giugliani ERJ. A prática do aleitamento materno nas capitais brasileiras e Distrito Federal: situação atual e avanços. J Pediatr. 2010; 86(4):317-24.
17. Saldiva SRDM, Venâncio SI, Gouveia AGC, Castro ALS, Escuder MML, Giugliani ERJ. Influência regional no consumo precoce de alimentos diferentes do leite materno em menores de seis meses residentes nas capitais brasileiras e Distrito Federal. Cad Saúde Pública. 2011; 27(11):2253-62.

18. Pereira RSV, Oliveira MIC, Andrade CLT, Brito AS. Fatores associados ao aleitamento materno exclusivo: o papel do cuidado na atenção básica. Cad Saúde Pública. 2010; 26(12):2343-54.

19. Organização Pan-Americana da Saúde. Condições de saúde e suas tendências - prevenção de riscos: lactação materna. In: Saúde nas Américas: 2007. Washington (DC): OPAS; 2007. p.154-6. v. 1 - Regional. Publicação Científica e Tecnológica, n. 622.

20. Venâncio SI, Monteiro CA. Individual and contextual determinants of exclusive breastfeeding in São Paulo, Brazil: A multilevel analysis. Public Health Nutr. 2006; 9(1):40-6.

21. Organização Pan-Americana da Saúde. Evidências científicas dos dez passos para o sucesso no aleitamento materno. Brasília: OPAS; 2001.

22. Santos IS, Matijasevich A, Barros AJD, Albernaz EP, Domingues MR, Valle NCJ, et al. Avoidable deaths in the first four years of life among children in the 2004 Pelotas (Brazil) birth cohort study. Cad Saúde Pública. 2011; 27(Suppl 2):s185-97.

23. Ramos CV, Almeida JAG, Alberto NSMC, Teles JBM, Saldiva SRDM. Diagnóstico da situação do aleitamento materno no Estado do Piauí, Brasil. Cad Saúde Pública. 2008; 24(8):1753-62.

24. Vieira GO, Martins CC, Vieira TO, Oliveira NF, Silva LR. Factors predicting early discontinuation of exclusive breastfeeding in the first month of life. J Pediatr. 2010; 86(5):441-4.

25. Caminha MFC, Batista FM, Serva VB, Arruda IKG, Figueiroa JN, Lira PIC. Tendências temporais e fatores associados à duração do aleitamento materno em Pernambuco. Rev Saúde Pública. 2010; 44(2): 240-8.

26. Demétrio F, Pinto EJ, Assis AMO. Fatores associados à interrupção precoce do aleitamento materno: um estudo de coorte de nascimento em dois municípios do Recôncavo da Bahia, Brasil. Cad Saúde Pública. 2012; 28(Supl 4):641-54.

27. Hannula L, Kaunonen M, Tarkka MT. A systematic review of professional support interventions for breastfeeding. J Clin Nurs. 2008; 17(9):1132-43.

28. World Health Organization. Community-based strategies for breastfeeding promotion and support in developing countries. Geneva: WHO; 2003.

29. Ciconi RCV, Venâncio SI, Escuder MML. Avaliação dos conhecimentos de equipes do Programa de 
Saúde da Família sobre o manejo do aleitamento materno em um município da região metropolitana de São Paulo. Rev Bras Saúde Matern Infant. 2004; 4(2):193-202.

30. Caldeira AP, Aguiar GN, Magalhães WAC, Fagundes GC. Conhecimentos e práticas de promoção do aleitamento materno em equipes de saúde da família em Montes Claros, Minas Gerais, Brasil. Cad Saude Publica. 2007; 23(8):1965-70.

31. Caldeira AP, Fagundes GC, Aguiar GN. Intervenção educacional em equipes do Programa de Saúde da Família para promoção da amamentação. Rev Saúde Pública. 2008; 42(6):1027-233.

32. Brasil. Ministério da Saúde. Secretaria de Ciência, Tecnologia e Insumos Estratégicos. Avaliação da atenção ao pré-natal, ao parto e aos menores de um ano na Amazônia Legal e no Nordeste, Brasil, 2010. Brasília: Ministério da Saúde; 2013.

33. Aarts C, Kylberg E, Hornell A, Hofvander Y, MedhinGebre M, Greiner T. How exclusive is exclusive breastfeeding? A comparison of data since birth with current status data. Inte J Epidemiol. 2000; 29(6):1041-6.

34. Santos LMP, Paes-Sousa R, Silva JB, Victora CG. National Immunization Day: A strategy to monitor health and nutrition indicators. Bull World Health Org. 2008; 84(6): 474-9.

Received on: 18/3/2013

Final version on: 4/11/2013

Approved on: 26/11/2013 


\section{ATTACHED 1}

Sample distribution ( $\mathrm{n}$ and \%) and 95\% confidence interval according to sociodemographic, prenatal, delivery, and puerperium variables. Study municipalities in the Legal Amazon and Northeast regions, Brazil, 2010

(1 of 2)

\begin{tabular}{|c|c|c|c|c|c|c|c|c|c|}
\hline \multirow{3}{*}{ Variables } & \multicolumn{6}{|c|}{ Region } & \multirow{2}{*}{\multicolumn{3}{|c|}{ Total }} \\
\hline & \multicolumn{3}{|c|}{ Legal Amazon } & \multicolumn{3}{|c|}{ Northeast } & & & \\
\hline & $n$ & $\%$ & $95 \% \mathrm{Cl}$ & $n$ & $\%$ & $95 \% \mathrm{Cl}$ & $n$ & $\%$ & $95 \% \mathrm{Cl}$ \\
\hline \multicolumn{10}{|c|}{ Child's age (months) } \\
\hline 0 & 543 & 13.1 & $(11.7-14.5)$ & 626 & 12.2 & $(11.12-13.5)$ & 1,169 & 12.6 & $(11.7-13.5)$ \\
\hline 1 & 778 & 18.9 & $(17.3-20.6)$ & 960 & 20.7 & $(19.2-22.2)$ & 1,738 & 20.0 & $(18.9-21.1)$ \\
\hline 2 & 735 & 18.0 & $(16.5-19.6)$ & 889 & 17.4 & $(16.1-18.9)$ & 1,624 & 17.7 & $(16.7-18.7)$ \\
\hline 3 & 750 & 18.1 & $(16.7-19.7)$ & 890 & 18.2 & $(16.8-19.7)$ & 1,640 & 18.2 & $(17.1-19.2)$ \\
\hline 4 & 646 & 16.6 & $(15.14-18.2)$ & 773 & 15.7 & $(14.4-17.1)$ & 1,419 & 16.1 & $(15.1-17.1)$ \\
\hline 5 & 664 & 15.3 & $(13.9-16.8)$ & 806 & 15.8 & $(14.5-17.1)$ & 1,470 & 15.6 & $(14.6-16.6)$ \\
\hline \multicolumn{10}{|l|}{ Child's gender } \\
\hline Male & 2,122 & 51.4 & $(49.3-53.4)$ & 2,492 & 50.9 & $(49.1-52.7)$ & 4,614 & 51.1 & $(49.7-52.5)$ \\
\hline Female & 1,992 & 48.6 & $(46.6-50.7)$ & 2,450 & 49.1 & $(47.3-50.9)$ & 4,442 & 48.9 & $(47.5-50.3)$ \\
\hline \multicolumn{10}{|c|}{ Child's birth weight } \\
\hline Low & 247 & 5.9 & $(5.0-6.9)$ & 318 & 6.6 & $(5.7-7.5)$ & 565 & 6.3 & $(5.7-7.0)$ \\
\hline Normal & 3,817 & 94.1 & $(93.1-95.0)$ & 4,531 & 93.4 & $(92.5-94.3)$ & 8,348 & 93.7 & $(93.0-94.3)$ \\
\hline \multicolumn{10}{|c|}{ Mother's age (years) } \\
\hline$<20$ years & 899 & 22.2 & $(20.6-23.9)$ & 984 & 20.6 & $(19.1-22.1)$ & 1,883 & 21.2 & $(20.1-22.4)$ \\
\hline 20-34 years & 2,905 & 71.4 & $(69.5-73.2)$ & 3,424 & 70.0 & $(68.3-71.7)$ & 6,329 & 70.6 & $(69.3-71.8)$ \\
\hline$\geq 35$ years & 270 & 6.4 & $(5.5-7.5)$ & 458 & 9.4 & $(8.4-10.5)$ & 728 & 8.2 & $(7.5-8.9)$ \\
\hline \multicolumn{10}{|c|}{ Mother's education level } \\
\hline $0-7$ years & 1,070 & 26.9 & $(25.2-28.6)$ & 1,342 & 26.9 & $(25.3-28.5)$ & 2,412 & 26.9 & $(25.7-28.1)$ \\
\hline $8-10$ years & 1,266 & 31.6 & $(29.8-33.5)$ & 1,357 & 28.2 & $(26.6-29.9)$ & 2,623 & 29.6 & $(28.4-30.9)$ \\
\hline$\geq 11$ years & 1,745 & 41.5 & $(39.6-43.4)$ & 2,200 & 44.9 & $(43.1-46.7)$ & 3,945 & 43.5 & $(42.2-44.8)$ \\
\hline \multicolumn{10}{|l|}{ Mother's race } \\
\hline White & 740 & 17.4 & $(16.0-19.0)$ & 1,082 & 20.7 & $(19.3-22.1)$ & 1,822 & 19.3 & $(18.3-20.4)$ \\
\hline Brown/Black & 3,210 & 79.0 & $(77.4-80.6)$ & 3,667 & 76.3 & $(74.7-77.7)$ & 6,877 & 77.4 & (76.3-78.5) \\
\hline Native/Yellow & 147 & 3.5 & $(2.9-4.3)$ & 175 & 3.1 & $(2.6-3.7)$ & 322 & 3.3 & $(2.8-3.7)$ \\
\hline \multicolumn{10}{|c|}{ Residence location } \\
\hline Not capital & 1,688 & 55.7 & $(55.7-55.7)$ & 2,656 & 61.0 & $(61.0-61.0)$ & 4,344 & 58.8 & $(58.8-58.8)$ \\
\hline Capital & 2,428 & 44.3 & $(44.3-44.3)$ & 2,288 & 39.0 & $(39.0-39.0)$ & 4,716 & 41.2 & $(41.2-41.2)$ \\
\hline \multicolumn{10}{|l|}{ Prenatal care } \\
\hline No & 63 & 1.8 & $(1.3-2.5)$ & 69 & 1.5 & $(1.1-2.0)$ & 132 & 1.6 & $(1.3-2.0)$ \\
\hline Yes & 4,053 & 98.2 & $(97.5-98.7)$ & 4,875 & 98.5 & $(98.0-98.9)$ & 8,928 & 98.4 & $(98.0-98.7)$ \\
\hline \multicolumn{10}{|c|}{ Prenatal service } \\
\hline Public & 3,254 & 82.5 & $(81.0-83.9)$ & 3,852 & 80.1 & $(78.7-81.5)$ & 7,106 & 81.1 & $(80.0-82.1)$ \\
\hline Private & 736 & 17.5 & $(16.1-19.0)$ & 953 & 19.9 & $(18.5-21.3)$ & 1,689 & 18.9 & $(17.9-20.0)$ \\
\hline \multicolumn{10}{|c|}{ Prenatal advice on breastfeeding } \\
\hline No & 1,276 & 31.1 & $(29.3-33.0)$ & 1,256 & 26.8 & $(25.2-28.4)$ & 2,532 & 28.6 & $(27.4-29.8)$ \\
\hline Yes & 2,840 & 68.9 & $(67.0-70.7)$ & 3,688 & 73.2 & $(71.6-74.8)$ & 6,528 & 71.4 & $(70.2-72.6)$ \\
\hline \multicolumn{10}{|l|}{ Delivery } \\
\hline Surgical & 1,923 & 47.7 & $(45.7-49.8)$ & 2,398 & 49.1 & $(47.2-50.9)$ & 4,321 & 48.5 & $(47.2-49.9)$ \\
\hline Vaginal & 2,048 & 52.3 & $(50.2-54.3)$ & 2,376 & 50.9 & $(49.1-52.8)$ & 4,424 & 51.5 & $(50.1-52.8)$ \\
\hline \multicolumn{10}{|l|}{ Delivery facility } \\
\hline Public & 3,191 & 78.6 & $(77.0-80.1)$ & 3,836 & 78.5 & $(77.0-80.0)$ & 7,027 & 78.6 & $(77.5-79.6)$ \\
\hline Private & 783 & 19.3 & $(17.9-20.9)$ & 883 & 19.1 & $(17.8-20.6)$ & 1,666 & 19.2 & $(18.2-20.3)$ \\
\hline Other & 58 & 2.1 & $(1.5-2.8)$ & 109 & 2.3 & $(1.9-2.8)$ & 167 & 2.2 & $(1.9-2.6)$ \\
\hline
\end{tabular}




\section{ATTACHED 1}

Sample distribution ( $\mathrm{n}$ and \%) and 95\% confidence interval according to sociodemographic, prenatal, delivery, and puerperium variables. Study municipalities in the Legal Amazon and Northeast regions, Brazil, 2010

(2 of 2$)$

\begin{tabular}{|c|c|c|c|c|c|c|c|c|c|}
\hline \multirow{3}{*}{ Variables } & \multicolumn{6}{|c|}{ Region } & \multirow{2}{*}{\multicolumn{3}{|c|}{ Total }} \\
\hline & \multicolumn{3}{|c|}{ Legal Amazon } & \multicolumn{3}{|c|}{ Northeast } & & & \\
\hline & $n$ & $\%$ & $95 \% \mathrm{Cl}$ & $\mathrm{n}$ & $\%$ & $95 \% \mathrm{Cl}$ & $\mathrm{n}$ & $\%$ & $95 \% \mathrm{Cl}$ \\
\hline \multicolumn{10}{|c|}{ Breastfeeding in the first hour of life } \\
\hline No & 1,198 & 30.8 & $(29.0-32.7)$ & 1,780 & 40.1 & $(38.3-42.0)$ & 2,978 & 36.3 & $(35.0-37.7)$ \\
\hline Yes & 2,755 & 69.2 & $(67.3-71.0)$ & 2,980 & 59.9 & $(58.0-61.7)$ & 5,735 & 63.7 & $62.3-65.0)$ \\
\hline \multicolumn{10}{|c|}{ Rooming-in } \\
\hline No & 469 & 11.9 & $(10.6-13.5)$ & 614 & 12.5 & $(11.3-13.8)$ & 1,083 & 12.3 & $(11.4-13.3)$ \\
\hline Yes & 3,469 & 88.1 & $(86.5-89.4)$ & 4,121 & 87.5 & $(86.2-88.7)$ & 7,590 & 87.7 & $(86.7-88.6)$ \\
\hline \multicolumn{10}{|c|}{ Recent visit from health/FHS agent } \\
\hline No & 2,229 & 54.9 & $(53.1-56.7)$ & 2,189 & 45.6 & $(44.0-47.3)$ & 4,418 & 49.5 & $(48.2-50.7)$ \\
\hline Yes & 1,834 & 45.1 & $(43.3-46.9)$ & 2,708 & 54.4 & $(52.7-56.0)$ & 4,542 & 50.5 & $(49.3-51.8)$ \\
\hline
\end{tabular}

Note: FHS: Family Health Strategy; $95 \% \mathrm{Cl}$ : Confidence Interval of $95 \%$. 


\section{ATTACHED 2}

Exclusive breastfeeding prevalence (\%) and 95\% confidence interval according to sociodemographic. prenatal. delivery. and puerperium care. Study municipalities in the Legal Amazon and Northeast regions. Brazil, 2010

(1 of 2)

\begin{tabular}{|c|c|c|c|c|c|c|c|c|c|}
\hline \multirow{3}{*}{ Variables } & \multicolumn{6}{|c|}{ Region } & \multirow{2}{*}{\multicolumn{3}{|c|}{ Total }} \\
\hline & \multicolumn{3}{|c|}{ Legal Amazon } & \multicolumn{3}{|c|}{ Northeast } & & & \\
\hline & $\%$ & $95 \% \mathrm{Cl}$ & $p^{*}$ & $\%$ & $95 \% \mathrm{Cl}$ & $p^{*}$ & $\%$ & $95 \% \mathrm{Cl}$ & $p^{*}$ \\
\hline Child's age (months) & & & $<0.001$ & & & $<0.001$ & & & $<0.001$ \\
\hline 0 & 72.0 & $(66.5-76.8)$ & & 66.3 & $(61.3-70.9)$ & & 68.7 & $(65.0-72.1)$ & \\
\hline 1 & 57.5 & $(52.8-62.0)$ & & 54.5 & $(50.3-58.7)$ & & 55.7 & $(52.5-58.8)$ & \\
\hline 2 & 49.9 & $(45.1-54.8)$ & & 42.7 & $(38.5-47.0)$ & & 45.7 & $(42.5-49.0)$ & \\
\hline 3 & 39.5 & $(35.3-43.9)$ & & 32.5 & $(28.6-36.6)$ & & 35.4 & $(32.5-38.4)$ & \\
\hline 4 & 26.4 & $(21.9-31.5)$ & & 20.4 & $(17.0-24.2)$ & & 23.0 & $(20.1-26.0)$ & \\
\hline 5 & 11.6 & $(9.0-14.8)$ & & 13.3 & $(10.3-17.1)$ & & 12.6 & $(10.5-15.1)$ & \\
\hline Child's gender & & & 0.595 & & & 0.310 & & & 0.267 \\
\hline Male & 42.1 & $(39.3-44.9)$ & & 37.1 & $(34.7-39.7)$ & & 39.2 & $(37.3-41.1)$ & \\
\hline Female & 43.1 & $(40.3-46.0)$ & & 39.0 & $(36.5-41.5)$ & & 40.7 & $(38.8-42.6)$ & \\
\hline Child's birth weight & & & 0.736 & & & 0.116 & & & 0.133 \\
\hline Low & 41.1 & $(33.2-49.5)$ & & 38.6 & $(36.7-40.5)$ & & 36.0 & $(31.0-41.4)$ & \\
\hline Normal & 42.6 & $(40.5-44.7)$ & & 32.8 & $(26.4-39.8)$ & & 40.2 & $(38.9-41.6)$ & \\
\hline Mother's age (years) & & & 0.014 & & & 0.004 & & & $<0.001$ \\
\hline$<20$ years & 37.4 & $(33.4-41.6)$ & & 33.5 & $(29.6-37.6)$ & & 35.2 & $(32.3-38.1)$ & \\
\hline 20-34 years & 43.7 & $(41.3-46.1)$ & & 38.4 & $(36.3-40.6)$ & & 40.6 & $(39.0-42.2)$ & \\
\hline$\geq 35$ years & 48.1 & $(40.2-56.0)$ & & 45.6 & $(39.7-51.7)$ & & 46.4 & $(41.6-51.2)$ & \\
\hline Mother's education level & & & 0.409 & & & 0.114 & & & 0.064 \\
\hline $0-7$ years & 40.3 & $(36.5-44.2)$ & & 35.7 & $(32.3-39.2)$ & & 37.6 & $(35.1-40.2)$ & \\
\hline $8-10$ years & 42.7 & $(39.1-46.2)$ & & 37.0 & $(33.8-40.4)$ & & 39.5 & $(37.1-42.0)$ & \\
\hline$\geq 11$ years & 43.7 & $(40.6-46.8)$ & & 40.1 & $(37.4-42.8)$ & & 41.5 & $(39.5-43.5)$ & \\
\hline Mother's race & & & 0.105 & & & 0.087 & & & 0.056 \\
\hline White & 47.0 & $(42.2-51.9)$ & & 38.1 & $(34.3-42.1)$ & & 41.4 & $(38.4-44.5)$ & \\
\hline Brown/Black & 41.4 & $(39.2-43.7)$ & & 37.5 & $(35.4-39.5)$ & & 39.1 & $(37.6-40.7)$ & \\
\hline Native/Yellow & 45.0 & $(34.8-55.6)$ & 0.074 & 48.5 & $(39.3-57.9)$ & & 46.9 & $(40.1-54.0)$ & \\
\hline Residence location & & & & & & 0.680 & & & 0.312 \\
\hline Not capital & 41.0 & $(37.9-44.2)$ & & 38.3 & $(35.8-40.9)$ & & 39.4 & $(37.4-41.4)$ & \\
\hline Capital & 44.5 & $(42.3-46.8)$ & & 37.6 & $(35.5-39.8)$ & & 40.7 & $(39.1-42.3)$ & \\
\hline Prenatal care & & & 0.537 & & & $<0.001$ & & & 0.044 \\
\hline No & 47.5 & $(32.2-63.4)$ & & 13.1 & $(6.5-24.5)$ & & 29.0 & $(20.2-39.8)$ & \\
\hline Yes & 42.5 & $(40.5-44.5)$ & & 38.4 & $(36.6-40.2)$ & & 40.1 & $(38.7-41.4)$ & \\
\hline Prenatal service & & & 0.845 & & & 0.127 & & & 0.303 \\
\hline Public & 42.4 & $(40.2-44.7)$ & & 37.6 & $(35.5-39.6)$ & & 39.6 & $(38.1-41.1)$ & \\
\hline Private & 41.9 & $(37.5-46.5)$ & & 41.0 & $(37.1-45.0)$ & & 41.3 & $(38.4-44.4)$ & \\
\hline Prenatal advice on breastfeeding & & & 0.676 & & & 0.335 & & & 0.244 \\
\hline No & 43.2 & $(39.7-46.8)$ & & 39.5 & $(36.1-42.9)$ & & 41.1 & $(38.7-43.6)$ & \\
\hline Yes & 42.3 & $(39.9-44.7)$ & & 37.5 & $(35.4-39.6)$ & & 39.4 & $(37.8-41.0)$ & \\
\hline Delivery & & & 0.662 & & & 0.087 & & & 0.113 \\
\hline Surgical & 42.9 & $(40.0-45.9)$ & & 39.8 & $(37.2-42.4)$ & & 41.0 & $(39.1-43.0)$ & \\
\hline Vaginal & 42.0 & $(39.2-44.9)$ & & 36.6 & $(34.0-39.2)$ & & 38.8 & $(36.9-40.8)$ & \\
\hline
\end{tabular}




\section{ATTACHED 2}

Exclusive breastfeeding prevalence (\%) and 95\% confidence interval according to sociodemographic. prenatal. delivery. and puerperium care. Study municipalities in the Legal Amazon and Northeast regions. Brazil, 2010

(2 of 2)

\begin{tabular}{|c|c|c|c|c|c|c|c|c|c|}
\hline \multirow{3}{*}{ Variables } & \multicolumn{6}{|c|}{ Region } & \multirow{2}{*}{\multicolumn{3}{|c|}{ Total }} \\
\hline & \multicolumn{3}{|c|}{ Legal Amazon } & \multicolumn{3}{|c|}{ Northeast } & & & \\
\hline & $\%$ & $95 \% \mathrm{Cl}$ & $p^{*}$ & $\%$ & $95 \% \mathrm{Cl}$ & $p^{*}$ & $\%$ & $95 \% \mathrm{Cl}$ & $p^{*}$ \\
\hline Delivery facility & & & 0.662 & & & 0.168 & & & 0.694 \\
\hline Public & 43.2 & $(40.9-45.5)$ & & 37.3 & $(35.3-39.3)$ & & 39.7 & $(38.2-41.3)$ & \\
\hline Private & 39.8 & $(35.5-44.3)$ & & 41.6 & $(37.5-45.9)$ & & 40.9 & $(37.9-44.0)$ & \\
\hline Other & 37.1 & $(23.6-53.0)$ & 0.362 & 37.6 & $(27.0-49.6)$ & & 37.4 & $(28.8-46.9)$ & \\
\hline Breastfeeding in the first hour of life & & & & & & 0.190 & & & 0.003 \\
\hline No & 37.9 & $(34.3-41.8)$ & & 36.6 & $(33.7-39.7)$ & & 37.1 & $(34.8-39.5)$ & \\
\hline Yes & 44.4 & $(42.0-46.9)$ & & 39.2 & $(36.9-41.5)$ & & 41.5 & $(39.8-43.2)$ & \\
\hline Rooming-in & & & 0.005 & & & 0.641 & & & 0.245 \\
\hline No & 38.7 & $(32.6-45.1)$ & & 36.9 & $(31.8-42.4)$ & & 37.6 & $(33.7-41.8)$ & \\
\hline Yes & 42.9 & $(40.8-45.1)$ & & 38.3 & $(36.4-40.3)$ & & 40.2 & $38.8-41.7)$ & \\
\hline Recent visit from health/FHS agent & & & 0.213 & & & 0.024 & & & 0.001 \\
\hline No & 44.4 & $(41.8-47.0)$ & & 40.3 & $(37.8-4) 3.0$ & & 42.2 & $(40.4-44.1)$ & \\
\hline Yes & 40.0 & $(37.0-43.2)$ & & 36.2 & $(33.7-38.7)$ & & 37.6 & $(35.7-39.6)$ & \\
\hline & & & 0.033 & & & & & & \\
\hline
\end{tabular}

Note: ${ }^{*}$ Chi-square test.

FHS: Family Health Strategy; $95 \% \mathrm{Cl}$ : Confidence Interval of $95 \%$. 


\section{ATTACHED 3}

Exclusive breastfeeding Prevalence Ratio (PR) and respective $95 \% \mathrm{Cl}$ adjusted for all variables according to sociodemographic, prenatal, delivery, and puerperium variables. Study municipalities of the Legal Amazon and Northeast regions, Brazil, 2010

\begin{tabular}{|c|c|c|c|c|c|c|}
\hline \multirow{2}{*}{ Variables } & \multicolumn{3}{|c|}{ Legal Amazon } & \multicolumn{3}{|c|}{ Northeast } \\
\hline & PR & $95 \% \mathrm{Cl}$ & $p$ & PR & $95 \% \mathrm{Cl}$ & $p$ \\
\hline Child's age (months) & & & 0.000 & & & 0.000 \\
\hline 0 & 1 & & & 1 & & \\
\hline 1 & 0.77 & $(0.69-0.87)$ & & 0.81 & $(0.73-0.91)$ & \\
\hline 2 & 0.68 & $(0.60-0.78)$ & & 0.65 & $(0.57-0.74)$ & \\
\hline 3 & 0.53 & $(0.46-0.62)$ & & 0.47 & $(0.40-0.55)$ & \\
\hline 4 & 0.37 & $(0.30-0.45)$ & & 0.30 & $(0.24-0.36)$ & \\
\hline 5 & 0.16 & $(0.12-0.21)$ & & 0.20 & $(0.15-0.27)$ & \\
\hline Child's gender & & & 0.266 & & & 0.598 \\
\hline Male & 1 & & & 1 & & \\
\hline Female & 1.06 & $(0.96-1.16)$ & & 1.03 & $(0.93-1.13)$ & \\
\hline Child's birth weight & & & 0.910 & & & 0.437 \\
\hline Low & 1 & & & 1 & & \\
\hline Normal & 1.01 & $(0.82-1.25)$ & & 1.09 & $(0.88-1.35)$ & \\
\hline Mother's age (years) & & & 0.012 & & & 0.001 \\
\hline$<20$ years & 1 & & & 1 & & \\
\hline 20-34 years & 1.14 & $(1.00-1.30)$ & & 1.14 & $(1.00-1.31)$ & \\
\hline$\geq 35$ years & 1.28 & $(1.03-1.58)$ & & 1.42 & $(1.17-1.71)$ & \\
\hline Mother's education level (years) & & & 0.470 & & & 0.128 \\
\hline $0-7$ years & 1 & & & 1 & & \\
\hline $8-10$ years & 1.02 & $(0.89-1.16)$ & & 1.07 & $(0.93-1.22)$ & \\
\hline$\geq 11$ years & 1.06 & $(0.93-1.20)$ & & 1.10 & $(0.97-1.25)$ & \\
\hline Mother's race & & & 0.106 & & & 0.840 \\
\hline White & 1 & & & 1 & & \\
\hline Brown/Black & 0.91 & $(0.80-1.04)$ & & 0.97 & $(0.86-1.09)$ & \\
\hline Native/Yellow & 0.83 & $(0.61-1.12)$ & & 1.18 & $(0.97-1.44)$ & \\
\hline Residence location & & & 0.004 & & & 0.725 \\
\hline Not capital & 1 & & & 1 & & \\
\hline Capital & 1.17 & $(1.05-1.30)$ & & 0.98 & $(0.90-1.08)$ & \\
\hline \multicolumn{7}{|l|}{ Received prenatal care } \\
\hline No & 1 & & & 1 & & \\
\hline Yes & omitted & & & omitted & & \\
\hline Prenatal carel service & & & 0.999 & & & 0.827 \\
\hline Public & 1 & & 0.999 & 1 & & \\
\hline Private & 1.00 & $(0.85-1.18)$ & 0.663 & 1.02 & $(0.88-1.18)$ & \\
\hline Prenatal advice on breastfeeding & & & & & & 0.986 \\
\hline No & 1 & & & 1 & & \\
\hline Yes & 0.98 & $(0.88-1.08)$ & 0.548 & 1.00 & $(0.90-1.12)$ & \\
\hline Delivery & & & & & & 0.101 \\
\hline Surgical & 1 & & & 1 & & \\
\hline Vaginal & 0.97 & $(0.87-1.08)$ & 0.198 & 0.92 & $(0.83-1.02)$ & \\
\hline Delivery facility & & & & & & 0.734 \\
\hline Public & 1 & & & 1 & & \\
\hline Private & 0.89 & $(0.75-1.06)$ & & 1.03 & $(0.88-1.20)$ & \\
\hline Other & 0.76 & $(0.45-1.28)$ & & 1.05 & $(0.69-1.60)$ & \\
\hline
\end{tabular}




\section{ATTACHED 3}

Exclusive breastfeeding Prevalence Ratio (PR) and respective $95 \% \mathrm{Cl}$ adjusted for all variables according to sociodemographic, prenatal, delivery, and puerperium variables. Study municipalities of the Legal Amazon and Northeast regions, Brazil, 2010

(2 of 2)

\begin{tabular}{|c|c|c|c|c|c|c|}
\hline \multirow{2}{*}{ Variables } & \multicolumn{3}{|c|}{ Legal Amazon } & \multicolumn{3}{|c|}{ Northeast } \\
\hline & PR & $95 \% \mathrm{Cl}$ & $p$ & PR & $95 \% \mathrm{Cl}$ & $p$ \\
\hline Breastfeeding in the first hour of life & & & 0.012 & & & 0.063 \\
\hline No & 1 & & & 1 & & \\
\hline Yes & 1.16 & $(1.03-1.30)$ & & 1.10 & $(0.99-1.21)$ & \\
\hline Rooming-in & & & 0.925 & & & 0.739 \\
\hline No & 1 & & & 1 & & \\
\hline Yes & 1.01 & $(0.85-1.200)$ & & 0.98 & $(0.89-1.09)$ & \\
\hline Recent visit from health/FHS agent & & & 0.449 & & & 0.733 \\
\hline No & 1 & & & 1 & & \\
\hline Yes & 0.96 & $(0.86-1.07)$ & & 0.98 & $(0.85-1.13)$ & \\
\hline
\end{tabular}

Note: FHS: Family Health Strategy; $95 \% \mathrm{Cl}$ : Confidence Interval of $95 \%$. 
